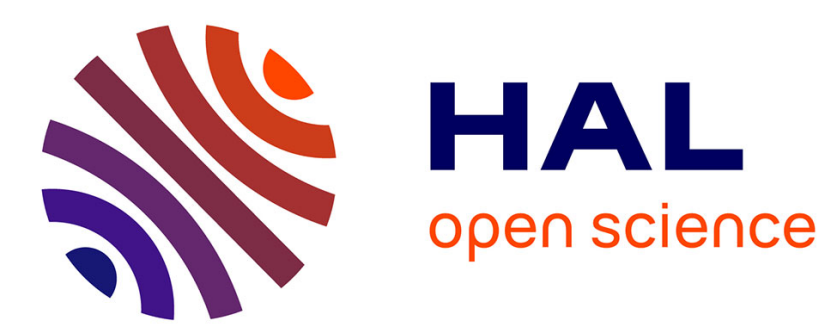

\title{
What is the cost of low participation in French timber auctions?
}

Raphaële Préget, Patrick Waelbroeck

\section{To cite this version:}

Raphaële Préget, Patrick Waelbroeck. What is the cost of low participation in French timber auctions?. Applied Economics, 2012, 44 (11), pp.1337-1346. 10.1080/00036846.2010.539546 . hal-02643188

\section{HAL Id: hal-02643188 \\ https://hal.inrae.fr/hal-02643188}

Submitted on 1 Sep 2020

HAL is a multi-disciplinary open access archive for the deposit and dissemination of scientific research documents, whether they are published or not. The documents may come from teaching and research institutions in France or abroad, or from public or private research centers.
L'archive ouverte pluridisciplinaire HAL, est destinée au dépôt et à la diffusion de documents scientifiques de niveau recherche, publiés ou non, émanant des établissements d'enseignement et de recherche français ou étrangers, des laboratoires publics ou privés. 


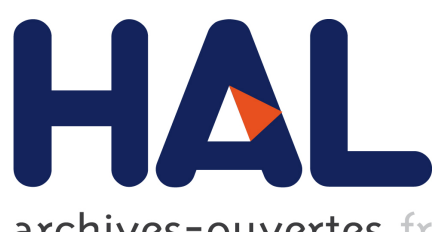

archives-ouvertes

\title{
What is the cost of low participation in French Timber auctions?
}

\author{
Raphaële Préget
}

\section{To cite this version:}

Raphaële Préget. What is the cost of low participation in French Timber auctions?. Applied Economics, Taylor \& Francis (Routledge), 2011, pp.1. 10.1080/00036846.2010.539546 . hal-00670762

\section{HAL Id: hal-00670762 \\ https://hal.archives-ouvertes.fr/hal-00670762}

Submitted on 16 Feb 2012

HAL is a multi-disciplinary open access archive for the deposit and dissemination of scientific research documents, whether they are published or not. The documents may come from teaching and research institutions in France or abroad, or from public or private research centers.
L'archive ouverte pluridisciplinaire HAL, est destinée au dépôt et à la diffusion de documents scientifiques de niveau recherche, publiés ou non, émanant des établissements d'enseignement et de recherche français ou étrangers, des laboratoires publics ou privés. 


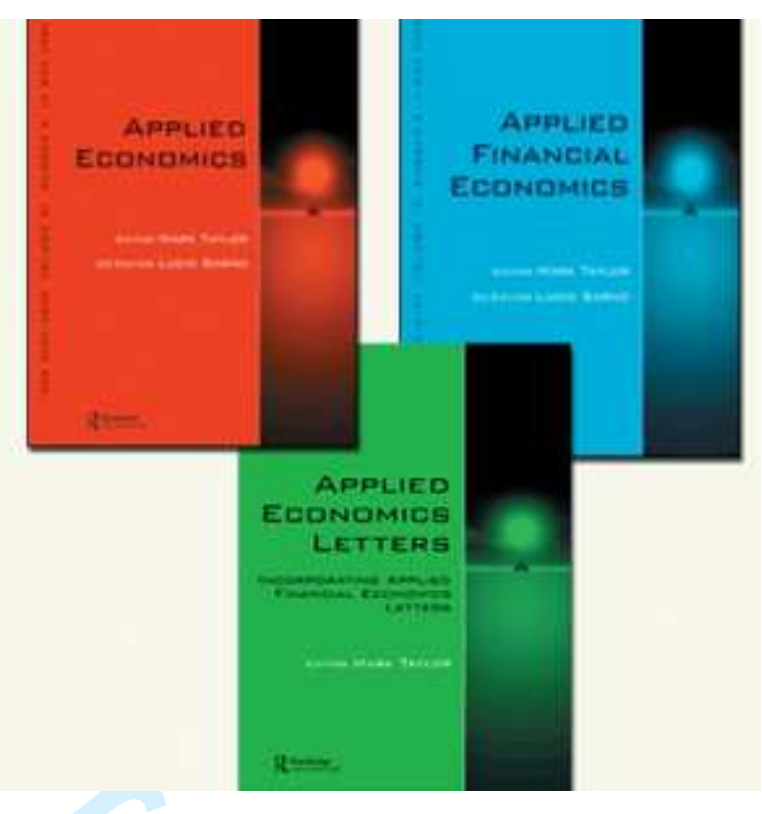

\section{What is the cost of low participation in French Timber auctions?}

\begin{tabular}{|c|c|}
\hline Journal: & Applied Economics \\
\hline Manuscript ID: & APE-08-0734.R1 \\
\hline Journal Selection: & Applied Economics \\
\hline $\begin{array}{r}\text { Date Submitted by the } \\
\text { Author: }\end{array}$ & 28-Sep-2010 \\
\hline Complete List of Authors: & Préget, Raphaële; INRA, LAMETA \\
\hline JEL Code: & $\begin{array}{l}\text { C11 - Bayesian Analysis < C1 - Econometric and Statistical } \\
\text { Methods: General < C - Mathematical and Quantitative Methods, } \\
\text { C34 - Truncated and Censored Models < C3 - Econometric } \\
\text { Methods: Multiple/Simultaneous Equation Models < C - } \\
\text { Mathematical and Quantitative Methods, D44 - Auctions < D4 - } \\
\text { Market Structure and Pricing < D - Microeconomics, L73 - Forest } \\
\text { Products: Lumber and Paper < L7 - Industry Studies: Primary } \\
\text { Products and Construction < L - Industrial Organization }\end{array}$ \\
\hline Keywords: & $\begin{array}{l}\text { timber auctions, hedonic prices, sample selection, endogenous } \\
\text { participation }\end{array}$ \\
\hline
\end{tabular}




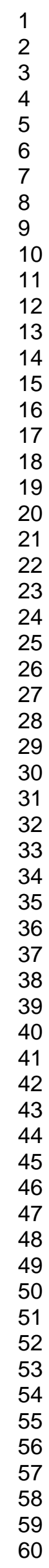

\section{SCHOLARONE ${ }^{m}$ \\ Manuscripts}

7

25

26

27

29

30

32

33

34

35

36

37

39

40

41

42

44

45

46

47

48

49

50

52

53

54

56

57

58

60 


\title{
What is the cost of low participation in French Timber auctions?
}

\author{
R. Préget ${ }^{\mathrm{a}, *}$ and P. Waelbroeck ${ }^{\mathrm{b}}$ \\ How much is the standing timber from public forests worth? To estimate the value of a timber lot we \\ adopt the transaction-evidence appraisal approach using data from timber auctions in Lorraine \\ (Eastern France) accounting for the facts that: (i) the seller's reserve prices are secret, (ii) there remain \\ many unsold lots, and (iii) the number of bidders varies across auctions. Taking into account the \\ endogenous participation in our hedonic price equation for the highest bid, we estimate that, \\ compared to lots that receive two bids, the highest bid is $22 \%$ lower when there is only one bid and \\ $37 \%$ higher when there are three or more bids.
}

\section{Introduction}

Fifty percent of hardwood timber lots in public timber auctions in Lorraine (Eastern France) received zero, one or only two bids and $42 \%$ of lots have not been auctioned. Moreover, $40 \%$ of auctioned lots were sold under the seller's secret reserve price. Low participation is a real issue in French public timber auction. But more generally, how much is the timber from public forests worth? How can the Public Forest Service define a fair market price for standing timber lots? Answering these questions is challenging. First, it is difficult to refer to production costs. Indeed, a forest takes time to grow and expand. Timber supply is more a harvesting decision based on silvicultural motives and related to the management of a renewable natural

\footnotetext{
a INRA, LAMETA, F-34000 Montpellier, France

${ }^{*}$ Corresponding author. E-mail: preget@ supagro.inra.fr

${ }^{\mathrm{b}}$ Telecom ParisTech, Paris, France
} 
resource, than just a question of wood production. Secondly, the Public Forest Service wants to maximize sales receipts, but also has other objectives, such as securing the timber supply to the wood local industry at a price that allows them to remain competitive on international markets and/or against other industries (steel, aluminum). Thus, the objectives of the seller are multiple and eventually contradictory. Third, standing timber is different from perishable goods. If the lot remains unsold, the trees continue to grow and the forest still offers other values (recreation, carbon sequestration, biodiversity) that are difficult to take into account when defining the value of a timber lot. To sum up, it is difficult for the seller to evaluate her own reservation value.

Yet, even if the Public Forest Service uses auctions to set the prices, the sales director needs to determine a relevant reserve price for each lot. Given that assessing the value of a standing timber lot is challenging, the seller will refer to demand factors such as: lot quality, species composition, lot location, harvesting conditions, etc. In this article, we use the so called "transaction evidence appraisal" (TEA) reduced form method, i.e. we estimate timber value from market prices obtained during past auctions in France.

Most French timber sales are sequential first-price sealed-bid auctions of heterogeneous lots. Heterogeneity is an important feature of standing timber sales. Lots differ from each other with respect to volume, composition, location, harvesting conditions, etc. (inter-lots heterogeneity). But a lot is also composed of trees of different species and qualities (intra-lot heterogeneity). These inter- and intra-lot heterogeneities raise various questions about valuation and optimal composition. 
Heterogeneity of timber lots makes the hedonic price function approach useful in order to infer appraisal value since many characteristics may influence the stumpage price.

There are two problems that arise when we analyze timber auction data. Both arise from the endogenous participation of the bidders. First, there are many lots for which there is no bid and there are good reasons to think that this outcome is not random: bidders may not bid on less attractive timber lots. It is important to note that in French timber auctions the seller does not announce any reserve price: it is kept secret. Thus, the lack of bids cannot be explained by a reserve price set too high, since no minimum amount is required to bid for a lot. Of course, lots with no submission remain unsold. However, we have to take lots without bids into account in order to prevent a possible sample selection bias. Secondly, when bids are submitted, the degree of competition varies across auctions. According to the independent private values auction model, in first-price auctions bidders bid more aggressively when the number of bidders increases. Since the number of bids cannot be explained by the value of the reserve price here, it is sensible to think that the number of bidders is driven by the characteristics of the lot. In other words, the number of bidders has to be included in the hedonic price equation as an endogenous explanatory variable.

From an econometric point of view, the main problem is related to the correlation between unobservable variables that determine the participation process and the auction result. We solve this challenge by specifying a 3-equation model: Equation 1 defines the probability that there is no bid, Equation 2 determines among submitted 
lots the degree of competition, and Equation 3 is the hedonic price equation. We estimate parameters of this system of simultaneous equations using a Bayesian Monte Carlo Markov Chain (MCMC) simulation algorithm. ${ }^{1}$

Our empirical work contributes to the literature on timber value appraisal by explicitly modeling the fact that the seller's reserve price is not announced. This is the main difference with the existing stumpage appraisal literature (discussed in section II) that uses the Tobit two-stage procedure. In this article, bidder participation directly depends on the characteristics of the timber lot. Secondly, we take into account the fact that bidders' participation is endogenous and we measure the cost of low competition in timber auctions.

Next section specifies our objective and our empirical approach through a survey of the literature on timber appraisal. Section III describes the institutional framework of French public timber auctions and the data. The methodology is detailed in section IV and section V presents the results. Section VI concludes.

\section{Timber appraisal}

It is not straightforward for the seller to know below which price she should not sell a timber lot. Theoretically, the seller's (reservation) value $v_{0}$ corresponds to the price under which the seller would get no profit from the transaction. That value is usually

\footnotetext{
${ }^{1}$ See Poirier and Tobias (2007) for a general introduction on this topic. The idea is to replace methods based on maximum likelihood that often do not converge in complicated settings.
} 
supposed to be exogenous, contrary to the reserve price which is strategically chosen by the seller. If the seller has perfect information on her private value $v_{0}$, the reserve price is never lower than $v_{0}$. But we claim that the seller does not perfectly know $v_{0}$ when the auction takes place. We can see $v_{0}$ as the best expected price that the seller could obtain in a future sale. That value depends on many features. For example, it depends not only on future global market conditions and macro variables, but also on how the market is valuing each characteristic of the lot. It is with respect to the latter feature that we want to improve timber appraisal.

We propose a reduced form procedure based on timber transaction evidence appraisal (TEA) to estimate the value of a timber lot and the cost of low participation in French timber auctions. The TEA method relies on the results of past timber sales for predicting stumpage prices. Unsold timber lots were not considered in early regression-based models (e.g. Jackson and McQuillan, 1979, McQuillan and Johnson-True, 1988). Prescott and Puttock (1990) and Puttock, Prescott and Meilke (1990) propose a standard hedonic price function to forecast stumpage prices in Southern Ontario timber sales; there was no unsold lots in their data. Buongiorno and Young (1984) modeled winning bids using OLS conditional on timber auctions that received at least two bids. However, as Huang and Buongiorno (1986) argued, the fact that some timber lots remained unsold is important market information. Thus, following transaction evidence appraisal models include this market information to prevent biased predictions. Since the reserve price is announced before the auctions in U.S. timber sales, it is assumed that the reserve price explains why some lots are not sold. Therefore, to take into account unsold lots, censored regressions (Tobit models) have been conducted (Huang and Buongiorno, 1986). 
Niquidet and van Kooten (2004) do not have sufficient information on no-bid auctions, so they seek to predict a fair market value of standing timber in British Columbia using a two-stage truncated regression procedure.

Beyond the treatment of unsold lots, the number of bidders also appears as an important variable in the estimation of the winning bid in stumpage appraisal literature. Indeed, the degree of competition in auctions has an impact on bidding strategies. Participants do not necessarily know the actual number of bidders, but they bid according to the expected or potential competition (Brannman 1996). Many studies on timber auctions such as Johnson (1979), Hansen (1986), Brannman, Klein and Weiss (1987) and Sendack (1991) empirically support the auction theory prediction that there is a positive relationship between the number of bidders and the value of the highest bid. Nevertheless, none of these studies endogenize participation. Examining the impact of the (announced) reserve prices in sealed-bid Federal timber auctions, Carter and Newman (1998) endogenize the number of bidders in a simultaneous-two-equations Tobit framework, but the expected number of bidders is determined strictly by the reserve price. Of course, this model does not fit French timber auctions since the reserve price is secret.

We propose to estimate a hedonic price function based on the highest bids. The highest bid of an auction is not necessary a winning bid since the seller might withdraw the lot if she believes that the highest bid is too low. However, we choose to estimate the highest bid because the sale price is not independent from the seller's decision and thus is less informative about market demand. 


\section{Data on French timber auctions}

Competitive bidding is widely used in timber sales in France. In particular, the French National Public Forest Service $\left(\mathrm{ONF}^{2}\right)$ uses first-price sealed-bid auctions. Timber auctions of ONF, which represent $40 \%$ of the timber sold each year in France, generally concern standing timber. The auction mechanism seems to be the best way to determine an "objective" or a "fair" market price for such a heterogeneous product. Before presenting the data, we describe the institutional framework.

Timber auctions are sequential auctions of heterogeneous goods. Usually more than one hundred lots are put on sale one after the other; the result of each auction is given before the next lot is put on sale. The first lot is randomly drawn, next the auctioneer follows the catalogue order. The sale catalogue details all the lots and is available to the bidders before the sale.

Potential buyers usually visit the lots they intend to buy, so as to infer their own private value. From a buyer's point of view, the estimated value of a lot is different than from the seller's point of view. Buyers have information on harvesting costs, on what they will produce with the wood and at what price they will be able to sell their products. It is therefore easier for them to estimate their reservation value for a given lot. That value depends on the characteristics of the lot, but may also depend on his inventory.

\footnotetext{
${ }^{2}$ ONF stands for Office National des Forêts.
} 
As mentioned above, and contrary to North American timber auctions, the reserve price is not announced in French public timber auctions. We believe that the seller prefers not to commit to any reserve price mainly because she does not know precisely her reservation value at the auction time as claimed in the previous section. Indeed, a (secret) reserve price is reported for each lot in the database, but this price is not the seller's reservation value since about $40 \%$ of auctioned lots are sold under that value. This means that the ONF decides to sell or not each lot at the last moment and does not commit to any reserve price so as to use the bids to adjust her valuation $v_{0}$. With this privilege, the seller keeps a certain flexibility to manage the sale, but that practice may be costly. Without credible commitment, ONF may lose a part of the benefit of an auction. If the bidders anticipate that the seller modifies her reserve price according to their bids, then they will modify their bidding strategy, which may lower the efficiency of the auction. Anyway, the fact that the seller updates her reserve prices shows her difficulty to assess $v_{0}$.

The dataset we use is part of the data collected by Costa and Préget (2004). It relies on the auction results of the ten fall 2003 timber sales of Lorraine, a Region of the eastern part of France. A total of 2262 lots were put on sale. Since there are many differences between hardwood and softwood valuations, we select only pure hardwood lots, i.e. lots that are composed of more than $99 \%$ of hardwood. Between September $9^{\text {th }}$ and October $28^{\text {th }} 2003,1205$ hardwood lots have been put on sale. The Herfindahl index is used to measure intra-lot heterogeneity. ${ }^{3}$ Out of the 1205 hardwood lots $48 \%$ correspond to previously unsold lots.

\footnotetext{
${ }^{3}$ The Herfindahl index is the sum of the square volume proportion of each species. Here the number of species is 7. The more homogeneous the lot, the closer is the index to one.
} 
Lots may be classified according to the auction results. A lot sold during the auction is "auctioned", whereas the others are "unsold lots". The percentage of unsold lots is $42 \%$ and shows a relatively difficult wood market environment in Lorraine during that period. It is useful to distinguish between lots that got one or more bids but have nevertheless been withdrawn by the seller and lots that got no bid at all, referred to as the "no bid" category. Table 1 presents sale results according to the number of bidders.

\section{[Insert Table 1]}

In our empirical application, we first propose to distinguish timber lots which received no bid and lots for which we observe at least one bid. Second, among the submitted lots, we distinguish 3 categories depending on the level of competition:

i) there is no competition: 1 bid,

ii) there is limited competition: 2 bids,

iii) there is strong competition: 3 bids or more.

The database includes more than one hundred variables that represent a large part of the information available in the catalogues. It also includes private information from ONF (harvesting conditions, quality of the lot, secret reserve price), data about the auction results (the number of bids, the auctioned prices) and computed data such as the Herfindahl index. This database is rich and exhaustive, it contains all the standing timber lots from public forests put on sale in the region during the fall of 2003. The following two tables give summary statistics of variables used in our econometric study. 
[Insert Table 2]

[Insert Table 3]

\section{Methodology}

Participation in timber auctions raises two econometric problems. First, many lots receive no bid and thus remain unsold. Secondly, the number of bidders has an impact on the result of the auction. Participation depends on the characteristics of the lots and thus is endogenous. We propose a reduced form econometric methodology that simultaneously deals with non-submitted lots (sample selection) and an endogenous number of bidders in the hedonic price function. We explicitly model participation by constructing $J$ categories; as announced, we consider 3 categories in our application: 1 bid, 2 bids, and 3 bids or more. We explain the intensity of participation by the characteristics of the lots in an ordinal probit framework.

We propose a Bayesian MCMC sampling algorithm. Indeed the existing maximum likelihood estimation procedures (such as simulated maximum likelihood) do not perform well with multiple correlation coefficients and sample selection (Waelbroeck, 2005). Thus, the idea is to simulate the (latent) variables that 
determine the participation outcomes, which greatly simplifies the analysis of the joint posterior distribution of the parameters. ${ }^{4}$

Despite the importance of the issue of sample selection with endogenous variables, we are not aware of a study that deals simultaneously with both issues. On the one hand, the problem of sample selection has been widely analyzed in the econometrics literature starting with the seminal work of Heckman, who proposed a method (Heckit) to correct sample selection bias. Van Hasselt (2005) has proposed a Bayesian MCMC algorithm to make inference on the correlation coefficient of the sample selection model. The author conducts a Monte Carlo study that shows that the Gibbs sampling algorithm performs well regardless of whether the parameters of the model are fully identified or not. ${ }^{5,6}$ On the other hand, Chakravarty and Li (2003) propose a Bayesian algorithm to test the effect of an endogenous binary variable on the profits of a trader (we are not aware of another similar study).

\footnotetext{
${ }^{4}$ Indeed, latent variables can be simulated and, conditional on these variables, the model is a simple Seemingly Unrelated Regression (SUR) model that is easy to deal with. We use a Metropolis step to draw from the conditional posterior distribution of the elements of the covariance matrix of the unobservable variables.

${ }^{5}$ The Gibbs algorithm is an MCMC algorithm that iteratively draws from the conditional posterior distributions of the parameters and always accepts such draws.

${ }^{6}$ We propose a slightly different MCMC algorithm for the sample selection part of the model than Van Hasselt (2005). We write the latent model as a SUR model with an unequal number of observations; and thus inference on the coefficients of the observed equation only relies on observations that are not censored.
} 
We analyze endogenous participation in French public timber auctions using a system of three equations. Equation 1 determines the selection process: it is the probability that there is at least one bid. In case the bidders do not participate in the auction (no bid), the expected payoff of participating, $w_{1, i}$, is zero or negative. Thus, we define $y_{1, i}=1$ if at least one bidder participates in the auction and $y_{1, i}=0$ otherwise where $i$ indexes the lots.

$$
y_{1, i}= \begin{cases}1 & \text { if } w_{1, i}>0 \\ 1 \quad & \text { if } w_{1, i} \leq 0\end{cases}
$$

where $w_{1, i}=\mathrm{x}_{1, i}{ }^{\prime} \beta_{1}+\varepsilon_{1, i}, \beta_{1}$ is of dimension $k_{1}$ and $\mathrm{x}_{1, i}$ is a set of control variables.

Equation 2 determines the outcome of the endogenous ordinal variable in the selected sample. We define $y_{2, i}$ as an ordinal variable that can take on $J$ values (in the application $J=3)$.

$$
\begin{array}{lll}
\mid & 1 & \text { if } w_{2, i} \leq \alpha_{1} \\
y_{2, i}=\{ & j & \text { if } \alpha_{j-1}<w_{2, i} \leq \alpha_{j}
\end{array}
$$

where $w_{2, i}=\mathrm{x}_{2, i}{ }^{\prime} \beta_{2}+\varepsilon_{2, i}, \beta_{2}$ is of dimension $k_{2}$ and $\mathrm{x}_{2, i}$ is a set of control variables.

We define $\alpha=\left(\alpha_{1}, \ldots, \alpha_{J-1}\right)^{\prime}$ as the vector of cutoff parameters to be estimated. 
Finally, Equation 3 is the hedonic price equation that explains the highest bid $w_{3, i}$ as a function of lot characteristics and the endogenous ordinal participation variable $y_{2, i}$ included as a set of $J-1$ binary variables. ${ }^{7}$ Equation 3 is only observed for lots that have received at least one bid $\left(y_{1, i}=1\right)$.

$$
w_{3, i}=\mathrm{z}_{3, i}{ }^{\prime} \gamma_{3}+z_{2, i}{ }^{\prime} \delta_{2}+\varepsilon_{3, i}=\mathrm{x}_{3, i}{ }^{\prime} \beta_{3}+\varepsilon_{3, i} \text { observed for } y_{1, i}=1
$$

where $\mathrm{z}_{2, i}=\left(z_{2,2, i}, \ldots, z_{2, J, i}\right)^{\prime}$ with $z_{2, j, i}=1$ if $y_{2, i}=j$ (and $z_{2, j, i}=0$ otherwise, $j=2, \ldots$ $J), \delta_{2}$ is a vector of parameters of dimension $J-1, \mathrm{x}_{3, i}=\left(\mathrm{z}_{3, i}{ }^{\prime}, z_{2, i}{ }^{\prime}\right)^{\prime}$ and $\beta_{3}=\left(\gamma_{3}{ }^{\prime}, \delta_{2}\right)^{\prime}$.

We assume that $\varepsilon_{i}=\left(\varepsilon_{1, i}{ }^{\prime}, \varepsilon_{2, i}{ }^{\prime}, \varepsilon_{3, i}{ }^{\prime}\right)^{\prime}$ is normally distributed with mean $(0,0,0)^{\prime}$ and covariance $\Sigma$ for $i=1, \ldots, n$ :

$$
\left.\Sigma=\quad \begin{array}{llll} 
& 1 & \rho_{12} & \rho_{13} \sigma_{3}
\end{array}\right]
$$

Parameters $\rho_{12}, \rho_{13}$ and $\rho_{23}$ represent the correlations between the unobservable variables. Hence, $\rho_{13}$ is the correlation coefficient of the Heckman sample selection procedure, while $\rho_{23}$ is related to the lack of competition for the lot in the hedonic

\footnotetext{
${ }^{7}$ We decompose the ordinal variable in a set of binary variables so that our results do not depend on the way we have coded the ordinal variable. This is not an issue in Equation 2 since the methodology automatically determine the cut-off points regardless of the values of the ordinal variable.
} 
price equation. Parameter $\sigma_{3}{ }^{2}$ is the variance of $\varepsilon_{3, i}$. Since probit Equation 1 and ordinal probit Equation 2 are not identified, we had to impose two restrictions. We chose to normalize the variances of the selection equation and of the endogenous binary variable to 1 . These are standard restrictions in probit models. ${ }^{8}$

We always observe $\left(\mathrm{x}_{1, i}, y_{1, i}\right)$, but we only observe $y_{2, i}$ and $w_{3, i}$ when $y_{1, i}=1 .{ }^{9}$ Moreover, the variables $w_{1, i}$ and $w_{2, i}$ are latent. The vector of explanatory variables can be stacked in order to write the (partially) latent model as a SUR model with an unequal number of observations. Let $n_{1}$ be the number of observations for which $y_{1, i}$ $=0$ and $n_{2}$ the number of observations such that $y_{1, i}=1$, with $n=n_{1}+n_{2}$. We now assume for notational convenience that the data have been sorted according to the values of $y_{1}$. We also note the vector of binary dependent variables as $\mathrm{y}=\left(\mathrm{y}_{1}{ }^{\prime}, \mathrm{y}_{2}{ }^{\prime}\right)^{\prime}$. Let $\beta=\left(\beta_{1}{ }^{\prime}, \beta_{2}{ }^{\prime}, \beta_{3}{ }^{\prime}\right)^{\prime}, w_{1}=\left(w_{1,1}, \ldots, w_{1, n}\right)^{\prime}, w_{2}=\left(w_{2,1}, \ldots, w_{2, n_{2}}\right)^{\prime}, w_{3}=\left(w_{3,1}, \ldots\right.$, $\left.\mathrm{w}_{3, n_{2}}\right)^{\prime}$ and define $\mathrm{w}=\left(\mathrm{w}_{1}{ }^{\prime}, \mathrm{w}_{2}{ }^{\prime}, \mathrm{w}_{3}{ }^{\prime}\right)^{\prime}$. We define $\varepsilon_{1}, \varepsilon_{2}, \varepsilon_{3}$ and $\varepsilon$ in a similar fashion.

For notational convenience, we decompose the vectors of unobservable variables according to the selection process: $\left.\varepsilon=\left(\varepsilon_{11}{ }^{\prime}, \varepsilon_{12}{ }^{\prime}, \varepsilon_{2}{ }^{\prime}, \varepsilon_{3}\right)^{\prime}\right)^{\prime}$, where the second index equals 1 if $y_{1, i}=0$ and equals 2 if $y_{1, i}=1$. Thus the covariance of the unobservable variables is simply

\footnotetext{
${ }^{8}$ See Wooldridge (2002) or any other textbook on the econometrics of qualitative dependant variable.

${ }^{9}$ The econometric model identifies all parameters associated with $\mathrm{x}_{1}, \mathrm{x}_{2}$ and $\mathrm{x}_{3}$ because of the nonlinearity of the Mill's ratio. However, in most sample selection specifications, some variables are usually not available for the censored observations, which means that the set of variables in $\mathrm{x}_{1}$ is usually smaller than in $\mathrm{x}_{2}$ and $\mathrm{x}_{3}$.
} 


$$
\Omega=\mathrm{E} \varepsilon \varepsilon^{\prime}=\left\lfloor\begin{array}{ccc}
\lceil & \mathrm{I}_{n_{1}} & 0 \\
0 & \Sigma \otimes \mathrm{I}_{n_{2}}
\end{array}\right]
$$

where $\mathrm{I}_{j}$ denotes the identity matrix of dimension $j \times j$. Thus $\Omega^{-1}$ is readily obtained. We also decompose and stack the vector of the partially latent dependent variables as $\mathrm{w}=\left(\mathrm{w}_{11}{ }^{\prime}, \mathrm{w}_{12}{ }^{\prime}, \mathrm{w}_{2}{ }^{\prime}, \mathrm{w}_{3}{ }^{\prime}\right)^{\prime}$ and define similarly

$$
\begin{aligned}
& \left\lceil\mathrm{x}_{11} \quad 0 \quad 0 \quad\right\rceil \\
& \mathrm{X}=\mid \begin{array}{lllll}
\mathrm{x}_{12} & 0 & 0 & \quad\left(n_{1}+3 n_{2}\right) \times\left(k_{1}+k_{2}+k_{3}\right)
\end{array} \\
& \begin{array}{llll}
0 & x_{2} & 0
\end{array} \mid \\
& \left\lfloor\begin{array}{llll}
0 & 0 & x_{3} & \rfloor
\end{array}\right.
\end{aligned}
$$

The (partially) latent model can be written in matrix format:

$$
\mathrm{w}=\mathrm{X} \beta+\varepsilon
$$

Hence conditional on $\mathrm{w}$ and $\Omega$, the estimates of $\beta$ are simply obtained by a Generalized Least Squares (GLS) regression of (4). ${ }^{10}$ Moreover, the matrices $X^{\prime} \Omega^{-1} X$ and $X^{\prime} \Omega^{-1}$ w required for the GLS estimates of the parameters of the model are easily computed.

\footnotetext{
${ }^{10}$ Since each stage contains different number of observations and generally different sets of explanatory variables, we can not estimate the SUR model with ordinary least squares regression applied to each latent equation separately.
} 
The 4 steps of the Metropolis-Gibbs algorithm and the computation of the partial effects are available upon request. We have used a flat prior in the Bayesian estimation of the parameters. The model can be extended to include informative prior so as to update implicit prices as the auction process moves on. However, with the large number observations that we have, this procedure is mostly relevant for the first auctions, given that at the end of the auction, the likelihood function will completely dominate the prior distribution in the posterior distribution. ${ }^{11}$

\section{Results}

Table 4 gives the Bayesian estimation of the 3 -equation model. ${ }^{12}$ All the variables available have been used to build the model but only significant variables have been kept in each equation. The signs of the estimated coefficients are coherent and intuitive, except for the variable 'no restriction' for which the coefficient is surprisingly negative in Equation 3.

\footnotetext{
${ }^{11}$ To conclude this methodological section, one could wonder if we need three equations. Our model could have been written within an ordered probit framework if one only uses one latent variable for the number of bidders (lots without bids are interpreted as censored observations). However this specification is not as flexible, because it implies that the unobservable variable that determine whether a lot receives at least one bid is perfectly correlated with the unobservable variable that determine the number of bidders conditional on a lot receiving at least one bid. There are indeed good reasons to believe that these unobservable variables are not perfectly correlated.

${ }^{12}$ Convergence of the MCMC algorithm was reach quickly. We removed the first 100000 iterations and kept the next 1000000 iterations for inference.
} 
Remember Equation 1 gives the probability that a lot will receive at least one bid. Equation 2 gives the intensity of competition (i.e the number of bidders). Equation 3 gives the estimated value of the log of the highest bid.

\section{[Insert Table 4]}

We also have estimated the probit Equation 1 and the ordinal probit Equation 2 separately and ran a Heckit procedure using sample selection Equation 1 and hedonic bid Equation 3 as benchmarks. Results were similar to the Bayesian estimation ${ }^{13}$. This is expected since the coefficient associated with the inverse Mills ratio is not significantly different from zero. However, this result is not reliable with the Heckit procedure and depends on the variables used to build the model. Actually, if we use only variables that are available in the sale catalogue, we may observe a selection bias while the Bayesian procedure does not detect any problem of sample selection bias. ${ }^{14}$ Therefore estimations of the correlation coefficients $\rho_{13}$ using the Heckit procedure can lead to misleading inference.

Controlling for endogenous participation and for the characteristics of the lots, we find that, compared to the highest bid for lots with two bids, on average: $(i)$ lots with only one bid receive a highest bid that is $22.31 \%$ below and (ii) lots with three or more bids receive a highest bid that is $37.09 \%$ higher. These results on the cost of low competition are very significant and imply that it is important for the seller to have enough bidders for each timber lot. This objective must be kept in mind when

\footnotetext{
${ }^{13}$ Results of these preliminary estimations are available upon request.

${ }^{14}$ Such a model is available upon request.
} 
she determines the number of lots to put on the market, their size and their composition. In addition, it would be wise to consider any improvement in the sale format that would lower the participation cost for any potential buyer.

Two other results deserve special mention. First, the degree of intra-lot heterogeneity is a significant variable in all 3 equations. Thus, competition increases for lots that are more homogenous in species, i.e. with an Herfindahl index closer to one. In addition, a higher Herfindahl index increases the highest bid. As shown by Boltz, Carter and Jacobson (2002) on prices of mixed species lots from timber auctions in North Carolina, increased heterogeneity leads to lower sale prices. In some way, they interpret such decrease in the revenue as an opportunity cost for ecosystem management where biodiversity is a desired constraint. Here, the opportunity cost of maintaining mixed forest can be estimated from the partial effect associated to the Herfindahl index: increasing the index by $1 \%$ increases the expected highest bid by $0.9164 \%$. This figure can be found in Table 5 which gives the partial effect for every variable. The partial effect of a variable corresponds to the total impact of that variable on the expected log of the highest bid taking into account the possible selection bias of non submitted lots and the impact of that variable on the number of bidders.

Second, the coefficient associated with the 'relative position of a lot' in the sale is significantly positive in Equations 2 and 3. This indicates that lots put on the market at the end of a sale have a higher probability to receive more bids and to obtain a better highest bid than lots auctioned in the beginning of the sale. This last result implies that the decline in prices often observed in sequential auctions is not present 
in our sample of timber auctions. On the contrary, prices tend to increase for hardwood lots during a sale. This could be due to cautious behavior of the bidders in the beginning and more aggressive bids at the end of the auction day. This interpretation is confirmed by two additional results. First, the probability that a lot receives at least one bid is significantly lower in the first sale of the campaign. The variable 'first sale' has a significant negative impact in Equations 1 and 2: bidders wait and see. Second, the variable 'last sale' has a significant positive impact in the hedonic price Equation 3. This result reinforces the 'relative position of a lot' variable on a larger scale. Indeed, the highest bid increases during a sale (which is composed of many timber lots put on sale the same day), moreover the highest bids tend to be higher in the tenth sale (the one that took place the last day of the timber sale campaign).

[Insert Table 5]

\section{Conclusion}

Using detailed data on timber auctions, we have highlighted the importance of endogenous participation on auction results, focusing on lots that do not receive any bids and on the degree of competition when lots receive at least one bid. We have proposed a methodology to deal with both issues at the same time. The econometric method can easily be extended to deal with truncated or censored dependant variables in the hedonic price equation, when the reserve price is announced. 
Our results can help public forest services to determine a relevant reserve price for each lot according to its characteristics. In addition, our hedonic price function for stumpage value gives interesting information about the implicit price of each lot characteristic for optimal lot composition. We have discussed the impact of the relative order of the lot in the sale and the impact of the intra-lot heterogeneity, but our results show that many variables have a significant impact on the participation process and on the highest bid including the type of cutting, the type of stand, the harvesting conditions, the volume and the composition of the lot. These results can help the forest public services to manage forest more efficiently so as to offer more attractive lots. Besides, our results highlight on the high cost of the low participation in French timber auctions and lead us to recommend any measure that would increase the number of bidders. In particular, it would be wise to implement any idea that would lower participating cost.

Finally, our methodology can also be useful for bidders to define a bid that increases their probability of winning at a lower cost. Models can be elaborated according to which variables are available to the agent just before the auction. 


\section{References}

Boltz F., Carter D., Jacobson M, 2002, "Shadow pricing diversity in U.S. national forests", Journal of Forest Economics, 8, 185-197.

Brannman L.E., 1996, "Potential competition and possible collusion in Forest Service Timber auctions", Economic Inquiry, 34, 730-745.

Brannman L.E., Klein D., Weiss L.W., 1987, "The price effects of increased competition in auction markets", Review of Economics and Statistics, 69, 24-32.

Buongiorno J., Young T., 1984, "Statistical appraisal of timber with an application to the Chequamegon National Forest", Northern Journal of Applied Forestry, 1, 7276.

Carter D.R., Newman D.H., 1998, "The impact of Reserve Prices in Sealed Bid Federal Timber Sale Auctions", Forest Science, 44, 485-495.

Chakravarty S., Li K, 2003, "A Bayesian Analysis of Dual Trader Informativeness in Future Markets," Journal of Empirical Finance, 10, 355-371.

Costa S., Préget R., 2004, "Étude de l'adéquation de l'offre en bois de l'Office National des Forêts à la demande de ses acheteurs", final report for ONF, pp. 112 Hansen R., 1986, "Sealed-Bid versus Open Auctions: The Evidence", Economic Inquiry, 24, 125-42.

Huang F.M., Buongiorno J., 1986, "Market Value of Timber When Some Offerings Are Not Sold: Implications for Appraisal and Demand Analysis", Forest Science, 32, 845-854. 
Jackson D.H., McQuillan A.G., 1979, "A technique for estimating timber value based on tree size, management variables, and market conditions", Forest Science, $25,620-626$.

Johnson R.N., 1979, "Oral Auction versus Sealed Bids: An Empirical Investigation", Natural Resources Journal, 19, 315-335.

McQuillan A.G., Johnson-True C., 1988, "Quantifying Marketplace Characteristics for Use in Timber Stumpage Appraisal", Western Journal of Applied Forestry, 3, 66-69.

Niquidet K., van Kooten C.G., 2004, "Are log markets competitive? Empirical evidence and implications for Canada-U.S. trade in softwood lumber", working paper 2004-04, Resource and Environmental economics and Policy Analysis Research Group, Department of Economics, University of Victoria, British Columbia, pp. 34 .

Poirier D.J., Tobias J.L., 2007, "Bayesian Econometrics", in Palgrave Handbook of Econometrics, vol. 1 Econometric Theory, Mills and Patterson (Eds.).

Prescott D.M., Puttock G.D., 1990, "Hedonic Price Functions for Multi-product Timber Sales in Southern Ontario", Canadian Journal of Agricultural Economics, 38, 333-344.

Puttock G.D., Prescott D.M., Meilke K.D., 1990, "Stumpage Prices in Southwestern Ontario: A Hedonic Function Approach", Forest Science, 36, 11191132.

Sendak P.E., 1991, "Timber sale value as a function of sale characteristics and number of bidders", Res. Pap. NE-657. Radnor, PA: U.S. Department of Agriculture, Forest Service, Northeastern Forest Experiment Station, pp.7. 
Van Hasselt M., 2005, "Bayesian Sampling Algorithms for the Sample Selection and the Two-Part Models", Computing in Economics and Finance ${ }^{\circ}{ }^{241}$, Society for Computational Economics.

Waelbroeck P., 2005, "Computational Issues in the Sequential Probit Model: A Monte Carlo Study," Computational Economics, 26, 141-161.

Wooldridge, J.M., 2002, Econometric analysis of cross section and panel data, MIT Press. 
Table 1. Timber auction results

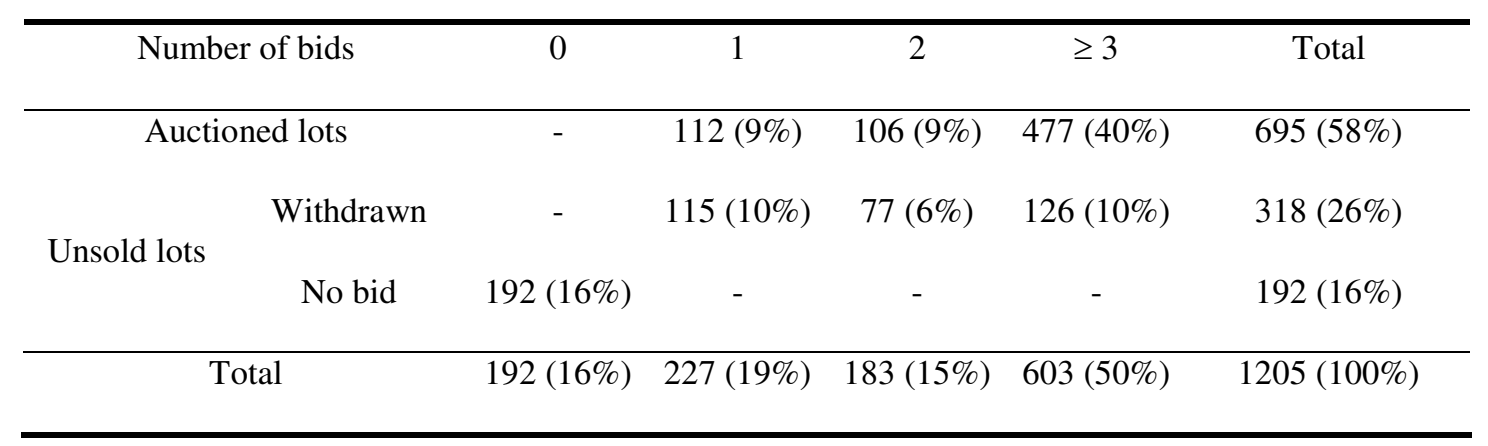


Table 2. Descriptive statistics for binary variables

\begin{tabular}{|c|c|}
\hline Variable & $\%$ \\
\hline No restrictions & 37.18 \\
\hline \multicolumn{2}{|l|}{ Cutting } \\
\hline arranged cutting & 52.70 \\
\hline other cutting & 4.40 \\
\hline selection cutting & 1.08 \\
\hline accidental products & 2.74 \\
\hline regeneration cutting & 39.09 \\
\hline Previously unsold & 48.22 \\
\hline \multicolumn{2}{|l|}{ Harvesting conditions } \\
\hline easy logging \& extraction & 27.22 \\
\hline normal logging & 58.76 \\
\hline difficult logging & 2.74 \\
\hline difficult logging \& extraction & 7.97 \\
\hline very difficult logging \& extraction & 3.15 \\
\hline \multicolumn{2}{|c|}{ Mitraille (scrap-iron, grape-shot from the first world war) } \\
\hline no mitraille & 77.56 \\
\hline light mitraille & 13.72 \\
\hline average mitraille & 5.99 \\
\hline heavy mitraille & 2.74 \\
\hline \multicolumn{2}{|l|}{ Stand, crop } \\
\hline high forest & 29.71 \\
\hline conversion of a stand & 62.41 \\
\hline coppice forest & 0.58 \\
\hline coppice with standards & 7.30 \\
\hline state-owned forest & 25.89 \\
\hline community-owned forest & 74.11 \\
\hline
\end{tabular}




\begin{tabular}{lc} 
unarranged & 80.41 \\
arranged & 15.93 \\
none & 3.65 \\
\hline Quality & 4.07 \\
very good & 34.85 \\
good & 45.64 \\
normal & 12.61 \\
mediocre & 2.66 \\
bad & \\
\hline
\end{tabular}


Table 3. Descriptive statistics for continuous variables

\begin{tabular}{lcccc}
\hline Variable & Mean & SD & Min & Max \\
\hline Surface (in hectare) & 12.41 & 10.38 & 0.20 & 104.04 \\
Number of trees & 238.27 & 205.63 & 21 & 2259 \\
Number of poles & 267.07 & 663.76 & 0 & 11366 \\
Herfindahl index & 0.6007 & 0.1949 & 0.3337 & 1.0000 \\
Stem volume of the mean-tree & 1.0623 & 0.7314 & 0.0596 & 4.7190 \\
Oak volume without crown & 94.51 & 115.98 & 0 & 859.98 \\
Beech volume without crown & 136.83 & 164.09 & 0 & 1365.80 \\
Other hardwood volume without crown & 67.66 & 97.25 & 0 & 838.60 \\
Crown hardwood volume & 166.62 & 153.64 & 0 & 1196.47 \\
Coppice volume & 0.33 & 5.39 & 0 & 153.83 \\
Relative order of the auction & 0.50 & 0.29 & 0 & 1 \\
\hline
\end{tabular}

Variables are defined in logs except variables in percentage. 
Table 4 - Bayesian estimation of the 3-equation model

\begin{tabular}{|c|c|c|c|}
\hline Variable & & Coef. & SD \\
\hline \multicolumn{4}{|l|}{ Equation 1} \\
\hline selection cutting \& other cutting & $* *$ & -0.4762 & 0.2188 \\
\hline accidental products & $* * *$ & -1.2381 & 0.2957 \\
\hline previously unsold & $* * *$ & -2.9745 & 0.4589 \\
\hline difficult $\&$ very difficult logging $\&$ extraction & $*$ & -0.2824 & 0.1513 \\
\hline Herfindahl index & $* *$ & 0.6432 & 0.3182 \\
\hline mitraille & $* *$ & -0.3139 & 0.1393 \\
\hline number of trees & $* * *$ & 0.3526 & 0.0773 \\
\hline arranged landing area & $* * *$ & 0.5380 & 0.1654 \\
\hline normal quality & $* * *$ & -0.5020 & 0.1429 \\
\hline mediocre \& bad quality & $* * *$ & -0.5174 & 0.1842 \\
\hline beech volume without crown & $*$ & 0.0726 & 0.0375 \\
\hline first sale & $* * *$ & -1.4172 & 0.1860 \\
\hline _cons & $* * *$ & 1.7395 & 0.6587 \\
\hline \multicolumn{4}{|l|}{ Equation 2} \\
\hline selection cutting \& other cutting & $* * *$ & -0.4899 & 0.1959 \\
\hline previously unsold & $* * *$ & -0.7265 & 0.0881 \\
\hline normal logging & $* * *$ & -0.3643 & 0.1033 \\
\hline difficult $\&$ very difficult logging $\&$ extraction & $* * *$ & -0.5620 & 0.1375 \\
\hline Herfindahl index & $* * *$ & 1.9769 & 0.3322 \\
\hline light mitraille & $* * *$ & -0.4324 & 0.1263 \\
\hline average mitraille & $* * *$ & -0.4563 & 0.1753 \\
\hline heavy mitraille & $* * *$ & -0.7949 & 0.2410 \\
\hline relative order of the auction & $* * *$ & 0.4587 & 0.1430 \\
\hline conversion of a stand & $* *$ & 0.2062 & 0.0989 \\
\hline arranged landing area & $* * *$ & 0.4106 & 0.1148 \\
\hline normal quality & $* * *$ & -0.2891 & 0.0924 \\
\hline
\end{tabular}




\begin{tabular}{|c|c|c|c|}
\hline mediocre \& bad quality & $* * *$ & -0.6658 & 0.1340 \\
\hline surface & $* * *$ & -0.2640 & 0.0818 \\
\hline other hardwood volume without crown & $* * *$ & 0.1603 & 0.0367 \\
\hline oak volume without crown & $* * *$ & 0.2575 & 0.0363 \\
\hline beech volume without crown & $* * *$ & 0.2094 & 0.0330 \\
\hline first sale & $* * *$ & -0.5220 & 0.1811 \\
\hline$\alpha_{1}$ & $* * *$ & 1.4265 & 0.4095 \\
\hline$\alpha_{2}$ & $* * *$ & 2.0618 & 0.0437 \\
\hline \multicolumn{4}{|l|}{ Equation 3} \\
\hline no restrictions & $* * *$ & -0.0884 & 0.0308 \\
\hline accidental products & $* * *$ & -0.4538 & 0.1116 \\
\hline regeneration cutting & $* * *$ & 0.1258 & 0.0311 \\
\hline previously unsold & $* * *$ & -0.1049 & 0.0366 \\
\hline density & $* * *$ & 0.0053 & 0.0011 \\
\hline difficult $\&$ very difficult logging $\&$ extraction & $* *$ & -0.0910 & 0.0384 \\
\hline Herfindahl index & $* * *$ & 0.9270 & 0.1412 \\
\hline mitraille & $* *$ & -0.0763 & 0.0348 \\
\hline number of trees & $* * *$ & 0.3735 & 0.0374 \\
\hline relative order of the auction & $* * *$ & 0.1635 & 0.0461 \\
\hline conversion of a stand & $* * *$ & 0.1413 & 0.0350 \\
\hline coppice forest \& coppice with standards & $* * *$ & 0.1978 & 0.0541 \\
\hline no landing area & $* *$ & -0.1563 & 0.0682 \\
\hline normal quality & $* * *$ & -0.1159 & 0.0298 \\
\hline mediocre \& bad quality & $* * *$ & -0.2261 & 0.0485 \\
\hline surface & $* * *$ & 0.2348 & 0.0438 \\
\hline other hardwood volume without crown & $* * *$ & 0.0581 & 0.0162 \\
\hline oak volume without crown & $* * *$ & 0.1885 & 0.0171 \\
\hline crown hardwood volume & $* * *$ & 0.0646 & 0.0099 \\
\hline beech volume without crown & $* * *$ & 0.0964 & 0.0145 \\
\hline stem volume of the mean-tree & $* * *$ & 0.4507 & 0.0269 \\
\hline
\end{tabular}




\begin{tabular}{llll} 
first sale & $*$ & 0.1139 & 0.0589 \\
last sale & $* * *$ & 0.1617 & 0.0355 \\
$y_{2}$ one bid & $* * *$ & -0.2231 & 0.0581 \\
$y_{2}$ three or more bids & $* * *$ & 0.3709 & 0.0657 \\
ccons & $* * *$ & 3.4837 & 0.1526 \\
\hline$\rho_{12}$ & & -0.0147 & 0.0581 \\
$\rho_{13}$ & & -0.0482 & 0.1296 \\
$\rho_{23}$ & & -0.0254 & 0.1242 \\
$\sigma_{3}$ & $* * *$ & 0.3837 & 0.0093 \\
\hline
\end{tabular}


Table 5 - Partial effects

\begin{tabular}{|c|c|c|c|}
\hline & & al effects & $\mathrm{SD}$ \\
\hline no restrictions & $* \star *$ & -0.0887 & 0.0313 \\
\hline selection cutting \& other cutting & & -0.0011 & 0.0230 \\
\hline accidental products & $* * *$ & -0.4139 & 0.1163 \\
\hline regeneration cutting & $* * *$ & 0.1253 & 0.0312 \\
\hline previously unsold & ** & -0.1725 & 0.0745 \\
\hline density & $* * *$ & 0.0053 & 0.0011 \\
\hline normal logging & * & -0.0102 & 0.0059 \\
\hline difficult \& very difficult logging \& extraction & $* * *$ & -0.1156 & 0.0411 \\
\hline Herfindahl index & $* * *$ & 0.9164 & 0.1580 \\
\hline mitraille & * & -0.0708 & 0.0384 \\
\hline light mitraille & * & -0.0115 & 0.0068 \\
\hline average mitraille & & -0.0121 & 0.0080 \\
\hline heavy mitraille & * & -0.0174 & 0.0103 \\
\hline number of trees & $* * *$ & 0.3352 & 0.0469 \\
\hline relative order of the auction & $* * *$ & 0.1791 & 0.0459 \\
\hline conversion of a stand & $* * *$ & 0.1472 & 0.0342 \\
\hline coppice forest \& coppice with standards & *** & 0.1989 & 0.0553 \\
\hline arranged landing area & & 0.0140 & 0.0249 \\
\hline no landing area & $* *$ & -0.1565 & 0.0667 \\
\hline normal quality & $* * *$ & -0.1125 & 0.0368 \\
\hline mediocre \& bad quality & $* * *$ & -0.2595 & 0.0531 \\
\hline surface & $* * *$ & 0.2265 & 0.0448 \\
\hline other hardwood volume without crown & $* * *$ & 0.0631 & 0.0159 \\
\hline oak volume without crown & $* * *$ & 0.1963 & 0.0166 \\
\hline crown hardwood volume & $* * *$ & 0.0648 & 0.0100 \\
\hline beech volume without crown & $* * *$ & 0.0949 & 0.0171 \\
\hline
\end{tabular}


